\title{
Relation of the disaccharidases in the small intestine of the rat to the degree of experimentally induced iron-deficiency anemia
}

M.R. Vieira,

L.C. Galvão and

M.I.M. Fernandes
Departamento de Puericultura e Pediatria, Faculdade de Medicina de Ribeirão Preto, Universidade de São Paulo, Ribeirão Preto, SP, Brasil

\section{Correspondence \\ L.C. Galvão \\ Departamento de Puericultura \\ e Pediatria, FM RP, USP \\ Av. Bandeirantes, 3900 \\ 14049-900 Ribeirão Preto, SP \\ Brasil \\ E-mail: Icgalvao@fmrp.usp.br}

Publication supported by FAPESP.

Received July 14, 1999

Accepted February 8,2000

\section{Abstract}

Hypolactasia associated with severe iron-deficiency anemia has been reported in several studies. The objective of the present study was to determine whether hypolactasia is associated with the degree and duration of iron-deficiency anemia. Newly weaned male Wistar rats were divided into a control group receiving a diet supplemented with iron (C) and an experimental group (E) receiving a diet not supplemented with iron (iron-deficiency diet). The animals were studied on the $3 \mathrm{rd}, 5 \mathrm{th}, 7 \mathrm{th}, 14 \mathrm{th}, 21 \mathrm{st}, 28 \mathrm{th}$ and $35 \mathrm{th}$ days of the experiment, when overall and iron nutritional status and disaccharidase activity in the small intestine were determined by the Dahlqvist method. A reduction in weight occurred in the anemic animals starting on the 5th day of the study. Anemia was present in the experimental animals, with a progressive worsening up to the 14th day (hemoglobin: $\mathrm{C}=$ 13.27 and $E=5.37$ ) and stabilizing thereafter. Saccharase and maltase activities did not differ significantly between groups, whereas lactase showed a significant reduction in total (TA) and specific activity (SA) in the anemic animals starting on the 21 st day of the study. Median lactase $\mathrm{TA}$ for the $\mathrm{C}$ and $\mathrm{E}$ groups was 2.27 and $1.25 \mathrm{U}$ on the 21 st day, 2.87 and $1.88 \mathrm{U}$ on the 28th day, and 4.20 and $1.59 \mathrm{U}$ on the 35 th day, respectively. Median lactase SA was 0.31 and $0.20 \mathrm{U} / \mathrm{g}$ wet weight on the $21 \mathrm{st}$ day, 0.39 and $0.24 \mathrm{U} / \mathrm{g}$ wet weight on the $28 \mathrm{th}$ day, and 0.42 and $0.23 \mathrm{U} / \mathrm{g}$ wet weight on the 35 th day, respectively. These findings suggest a relationship between the enzymatic alterations observed and both the degree and duration of the anemic process. Analysis of other studies on intestinal disaccharidases in anemia suggests that the mechanism of these changes may be functional, i.e., that the enterocytes may suffer a reduction in their ability to synthesize these enzymes.

\section{Introduction}

Iron-deficiency anemia is the most common nutritional deficiency in the world. One billion people are estimated to carry this deficiency $(1,2)$. In Brazil, Monteiro and
- Disaccharidases

- Lactase

- Anemia

- Iron deficiency

- Intestinal mucosa
Key words
Szarfarc (3) in 1987 detected anemia in 35.6\% of children younger than 5 years and concluded that this frequency has been increasing compared to a similar study conducted ten years before. Several alterations have been observed in children with iron-defi- 
ciency anemia, such as changes in physical growth and impairment of cognitive functions and of the immune response (4-7).

Some studies have demonstrated alterations in intestinal disaccharidase levels associated with iron-deficiency anemia. Hoffbrand and Broitman (8), in a study of puppy dogs submitted to chronic iron deficiency, detected a significant reduction in lactase, maltase and saccharase in the intestinal mucosa of these animals.

Sriratanaban and Thayer (9) studied disaccharidase activity in iron and protein nutritional deficiency in rats fed an iron-deficient diet, a protein-deficient diet and a combination of the iron- and protein-deficient diets. Their results showed that the animals fed the iron-deficient diet presented a reduction in disaccharidase activity without any histological changes, whereas the animals fed the protein-deficient diet alone or in association with iron did not present a deficiency in these enzymes.

Lanzkowsky et al. (10) also found a reduction in disaccharidase levels in anemic rats. These investigators also studied disaccharidase levels in 10 children with severe iron-deficiency anemia. In biopsies taken from these patients, they observed that all presented a reduced disaccharidase activity (11). Although the methodology used does not permit reaching definitive conclusions, this may be an important problem in anemic children with diarrhea.

Fernandes et al. (12) studied disaccharidase levels and cell proliferation in the small intestine of rats with iron-deficiency anemia and observed that the animals fed an irondeficient diet presented a reduction in total and specific lactase activity. Maltase and saccharase concentrations remained unchanged and cell proliferation did not differ between the anemic and control groups.

There are no studies on disaccharidase concentrations during the course of anemia and the available reports always refer to severe anemia. Thus, the objective of the present investigation was to study the relationship between disaccharidase deficiency and the degree and duration of anemia.

\section{Material and Methods}

A total of 84 male Wistar rats were used immediately after weaning (21 days) and studied for a period of 35 days. On the first day of the study the animals were weighed and submitted to capillary blood collection for the determination of hematocrit and hemoglobin. The animals were then placed in individual stainless steel cages with glass feeders and drinking water containers previously washed with a $10 \%$ nitric acid solution and rinsed with deionized water.

The rats were divided into two groups of 42 animals each, control and experimental, respectively receiving ration supplemented or not with iron. Basal casein ration was prepared according to the norms of the Association of Official Chemists, modified by Fritz et al. (13). The amount of iron added to the diet for the control group was $179.2 \mathrm{mg}$ ferrous sulfate per $\mathrm{kg}$ ration, corresponding to $36 \mathrm{mg}$ of iron. No iron was added to the diet for the experimental group. Ration was changed and the cages, feeders and drinking containers were washed daily at the same time of day. Both groups had free access to ration and to deionized water.

Four to six animals in each group were sacrificed on the 3rd, 5th, 7th, 14th, 21st, 28th and 35th day of the study. The animals were weighed and anesthetized with ether and capillary blood was collected for the determination of hematocrit and hemoglobin, and blood was collected by cardiac puncture for the determination of serum iron and total iron-binding capacity (TIBC) by the method of Ramsay (14).

The entire small intestine from the pylorus to the ileocecal valve was removed, washed internally and externally with icecold physiological saline, weighed and ground over ice in a Potter-Elvehjem-type 
tissue homogenizer, with about $1.0 \mathrm{ml}$ physiological saline. The homogenate was diluted with predetermined amounts of physiological saline according to intestinal weight and used for the determination of intestinal disaccharidases by the method of Dahlqvist (15).

Enzymatic activity is reported as units and one unit was defined as the amount of enzyme hydrolyzing $1 \mu \mathrm{mol}$ of the disaccharide in $1 \mathrm{~min}$ at $37^{\circ} \mathrm{C}$. Total disaccharidase activity was considered to be that obtained in the entire intestine, and specific activity was considered to be that calculated as units/g wet weight of small intestine.

\section{Statistical analysis}

Data were analyzed statistically by the nonparametric Mann-Whitney U-test, with the level of significance set at 5\% (16).

\section{Results}

Table 1 presents the weight, hematocrit and hemoglobin determined for each group during the experiment. It can be seen that there were no differences between groups in these parameters at the beginning of the study, a fact demonstrating the homogeneity of the groups studied in terms of overall and iron nutritional status. Statistical analysis showed differences between groups on the 5 th, 14th, 21st, 28th and 35th days of the study. Table 1 shows the values of hemoglobin, hematocrit, serum iron and TIBC for the two groups. The differences were significant for hemoglobin starting on the 3rd day and for the remaining parameters starting on the 5th day, with these values remaining unchanged thereafter.

Figure 1 presents the median for the total and specific activities of lactase, saccharase and maltase. Significant differences between groups were observed only on the 5th and 21 st day of the study for total saccharase activity, whereas specific activity was simi- lar in the two groups. Although it appears from Figure 1 that the total activities of these enzymes were different on days 14 and 35 , statistical analysis did not show a significant difference ( $\mathrm{P}=0.57$ and $\mathrm{P}=0.21$, respectively).

Significant differences between groups were observed on the $3 \mathrm{rd}$ and 21 st days of the study for total maltase activity, whereas specific activity was similar in the two groups. Again, a difference between groups appeared to be present on the 35th day but the level of significance was 0.22 .

Lactase was the enzyme whose activity underwent an important and prolonged reduction in the anemic group compared to the control. Statistical analysis showed that the differences were significant starting on the 21 st day for both activities.

\section{Discussion}

Hemoglobin levels were significantly lower in the experimental group starting on the 3rd day of the study, whereas the other parameters (hematocrit, serum iron and TIBC) became altered on the 5th day. Since hemoglobin is known to be the most adequate of these parameters for the diagnosis of iron-deficiency anemia $(17,18)$, we used this parameter to define the presence or absence of anemia in the experimental group compared to control.

The differences in saccharase and maltase activity observed on certain days did not persist throughout the experiment, a fact that impairs the interpretation of these findings. We believe that this fact was due to the wide amplitude of variation of the results obtained. An increased sample size would be necessary to solve this problem. The same comment can be made with respect to the difference in total lactase activity observed only on the 5th day.

The reduction in lactase concentrations observed here coincides with the data reported in the literature. However, Sriratana- 
ban and Thayer (9) and Lanzkowsky et al. (10) also detected a reduction in saccharase and maltase levels, a fact that did not occur in the present study. This difference may be explained by the fact that in the present study the animals were submitted to shorter periods of anemia. Indeed, the first of the two cited studies used rats born to anemic dams and suckled by these dams and submitted to an iron-poor diet for 75 to 185 days. Lanzkowsky et al. (10), in turn, detected differences in the 3 disaccharidases when they studied animals from the 21 st to the 84 th day of life, i.e., over a period of 9 weeks. Fernandes et al. (12) studied disac- charidase levels and cell proliferation in the small intestine of rats with iron-deficiency anemia also over a period of 5 weeks and detected a marked reduction in total and specific lactase activity and normal maltase and saccharase activity, in agreement with the present findings. The impression that there were differences in total activity between saccharase and maltase on the 35th day supports the hypothesis that a longer period of study would probably show differences also in the levels of these two enzymes.

In an attempt to relate changes in lactase to anemia level we observed that indeed

\begin{tabular}{|c|c|c|c|c|c|c|}
\hline $\begin{array}{l}\text { Period } \\
\text { (days) }\end{array}$ & Groups & $\begin{array}{l}\text { Weight } \\
\text { (g) }\end{array}$ & $\begin{array}{l}\text { Hemoglobin } \\
(\mathrm{g} / \mathrm{dl})\end{array}$ & $\begin{array}{l}\text { Hematocrit } \\
(\%)\end{array}$ & $\begin{array}{l}\text { Serum iron } \\
(\mu \mathrm{g} / 100 \mathrm{ml})\end{array}$ & $\begin{array}{c}\text { TIBC } \\
(\mu \mathrm{g} / 100 \mathrm{ml})\end{array}$ \\
\hline \multirow[t]{2}{*}{0} & $\mathrm{E}$ & $50.00(44-56)$ & $9.77(8.64-10.90)$ & $37.00(29.00-44.00)$ & - & - \\
\hline & $\mathrm{C}$ & $48.00(42-56)$ & $9.77(8.49-12.78)$ & $37.00(26.00-55.00)$ & - & - \\
\hline \multirow[t]{2}{*}{3} & $\mathrm{E}$ & $60.50(50-65)$ & $9.39 *(8.64-10.52)$ & $34.50(33.00-37.00)$ & $108.84(34.65-168.00)$ & $547.83(436.22-579.90)$ \\
\hline & $\mathrm{C}$ & $62.00(55-62)$ & $10.15(9.77-12.40)$ & $35.00(32.00-44.00)$ & $463.16(451.61-610.70)$ & $463.16(451.61-610.70)$ \\
\hline \multirow[t]{2}{*}{5} & $E$ & $73.00 *(61-77)$ & $7.51 *(6.01-10.90)$ & $30.00 *(26.00-37.00)$ & $63.52 *(25.00-102.02)$ & $592.45 *(523.46-672.20)$ \\
\hline & C & $82.00(77-86)$ & $10.52(9.77-10.90)$ & $37.00(36.00-39.00)$ & $183.00(123.00-242.55)$ & $478.66(454.18-528.59)$ \\
\hline \multirow[t]{2}{*}{7} & $\mathrm{E}$ & $75.00(63-79)$ & $7.40 *(5.48-8.27)$ & $27.50 *(15.00-28.00)$ & $63.00 *(50.00-116.00)$ & $673.50 *(595.30-695.30)$ \\
\hline & $\mathrm{C}$ & $74.50(69-83)$ & $12.22(9.02-15.03)$ & $43.50(35.00-45.00)$ & $197.50(118.00-302.2)$ & $516.00(477.20-626.10)$ \\
\hline \multirow[t]{2}{*}{14} & $\mathrm{E}$ & $93.00 *(80-111)$ & $5.37 *(4.88-6.01)$ & $21.50 *(19.00-22.00)$ & $42.00 *(31.00-71.00)$ & $664.55 *(595.30-713.34)$ \\
\hline & $\mathrm{C}$ & $116.50(102-127)$ & 13.27 (12.67-14.43) & $43.50(39.00-45.00)$ & $182.50(156.00-308.00)$ & $490.10(338.00-610.70)$ \\
\hline \multirow[t]{2}{*}{21} & $\mathrm{E}$ & $116.50 *(87-130)$ & $5.45 *(4.51-7.14)$ & $26.50 *(19.00-28.00)$ & $31.76 *(14.00-34.65)$ & $645.32 *(574.78-713.00)$ \\
\hline & $\mathrm{C}$ & 164.00 (150-167) & $13.00(12.40-14.66)$ & $45.00(41.00-46.00)$ & $242.55(154.00-292.60)$ & $418.00(382.33-459.00)$ \\
\hline \multirow[t]{2}{*}{28} & $\mathrm{E}$ & $115.50 *(102-158)$ & $5.77 *(4.66-6.91)$ & $25.00 *(22.00-28.00)$ & $33.00 *(29.00-54.00)$ & $683.80 *(620.90-846.00)$ \\
\hline & $\mathrm{C}$ & $204.00(178-216)$ & 13.91 (13.53-15.18) & $46.00(43.00-49.00)$ & $208.00(118.00-260.00)$ & $400.00(382.00-441.00)$ \\
\hline \multirow[t]{2}{*}{35} & $E$ & $151.00 *(100-200)$ & $4.88 *(4.43-5.63)$ & $21.00 *(15.00-27.00)$ & $38.00 *(31.00-55.80)$ & $597.80 *(564.00-713.00)$ \\
\hline & $\mathrm{C}$ & $253.00(236-268)$ & 15.07 (14.66-16.60) & $49.00(44.00-60.00)$ & $185.00(131.00-227.00)$ & $380.00(333.00-436.00)$ \\
\hline
\end{tabular}


there was a relationship since anemia increased in intensity during the experiment, with the onset of differences in lactase activity, as shown in Table 1 and Figure 1. Thus, we may infer that these enzymatic changes may not be present in mild and moderate anemia. Since we know that the iron-deficiency anemia commonly occurring in the pediatric population manifests in most cases as mild and moderate disease, it would be precipitated to consider these children to have hypolactasia. This possibility should be considered only in cases of severe anemia.

However, the duration of the process also seems to have been an important factor for this reduction since the degree of anemia was already quite marked on the 14th day (median hemoglobin $<7$ ), with little variation until the end of the experiment, and the differences in lactase appeared on the 21st day, i.e., they occurred after anemia had worsened. For a better interpretation of this result it would be interesting to study animals kept in a condition of mild and/or moderate anemia for a longer period of time.

Despite the significant difference in weight between animals on the 5th day, it was only after the 14th day that this difference was clearly detectable and persistent (Figure 1). This finding of weight deficiency associated with iron-deficiency anemia coincides with observations reported in the literature. Some investigators (19-21) have commented about the difficulty in determining whether the low weight gain associated with anemia is a consequence of anorexia, of DNA disorders or of disturbances in RNA synthesis, or of the functional changes in the small intestine which cause nutrient malabsorption. In our study, even though we did not quantify the amount of food ingested, we observed that the animals in the experimental group ate less than those in the control group. This weight reduction in anemic animals may reflect malnutrition as a possible cause of these differences in lactase activity. The malnutrition obtained in these animals was of the global type since it was not accompanied by changes in protein or albumin levels in blood (data not shown). Most studies of malnutrition and anemia in rats have demonstrated the absence of changes in disaccharidases in this type of nutritional disorder, with increased specific activity having indeed been reported (22). Furthermore, Fernandes et al. (12), using a similar methodology, observed the same phenomenon of malnutrition associated with anemia. In this study, anemic animals were allowed to recover from anemia and their lactase levels became normal without a reduction or disappearance of the difference in weight between the experimental and control animals.

The mechanism of this enzyme deficiency observed in iron-deficiency anemia has not been fully elucidated. Fernandes et al. (12) found no differences in small intestinal cell proliferation between anemic rats and controls, a fact suggesting the absence of morphological changes associated with this deficiency. Dallman et al. (23) detected cytochrome $\mathrm{C}$ deficiency in the intestine of rats with iron-deficiency anemia, a fact leading to the hypothesis of functional alterations of enterocytes in these animals. Supporting this idea, Buts et al. (24), using electron microscopy and kinetic studies of the small intes-

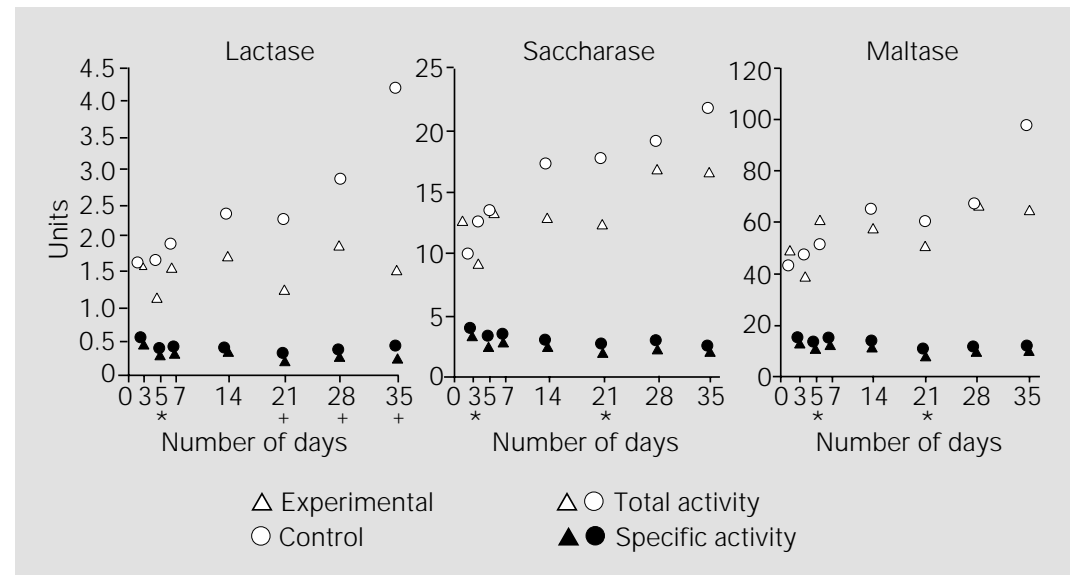

Figure 1 - Median total and specific lactase, saccharase and maltase activities in experimental and control animals on the 3rd, 5th, 7th, 14th, 21st, 28th and 35th days of the experiment. $* \mathrm{P}<0.05$ when total activity was compared (Mann-Whitney U-test); $+\mathrm{P}<0.05$ when total and specific activities were compared (Mann-Whitney U-test). 
tine of anemic animals with disaccharidase deficiency, detected changes in the secretory components of enterocytes with no alteration of erythrocyte membrane morphology, i.e., the ability of enterocytes to synthesize these enzymes may be reduced.

\section{Acknowledgments}

We wish to thank Ms. Aparecida Martinelli Gonçalves for valuable technical assistance throughout the experiment.

\section{References}

1. Dallman PR, Simes MA \& Stekel A (1980). Iron deficiency in infancy and childhood. American J ournal of Clinical Nutrition, 33: 86-118.

2. Lönnerdal B \& Dewey KG (1996). Epidemiologia da deficiência de ferro no lactente e na criança. Anais Nestlé, 52: 11-17.

3. Monteiro CA \& Szarfarc SC (1987). Estudo das condições de saúde das crianças no município de São Paulo, SP (Brasil), 19841985. Revista de Saúde Pública, 21: 255260.

4. Soemantri AG, Pollitt E \& Kim I (1985). Iron deficiency anemia and educational achievement. American J ournal of Clinical Nutrition, 42: 1221-1228.

5. Oski FA (1993). Iron deficiency in infancy and childhood. New England J ournal of Medicine, 329: 190-193.

6. Chwang L, Soemantri AG \& Pollitt E (1998). Iron supplementation and physical growth of rural Indonesian children. American J ournal of Clinical Nutrition, 47: 496-501.

7. Thibault $H$, Galan $P$, Selz $F$, Prezioli $P$, Badoual J \& Hercberg $S$ (1993). The immune response in iron-deficiency young children: effect of iron supplementation on cell-mediated immunity. European J ournal of Pediatrics, 152: 120-124.

8. Hoffbrand AV \& Broitman SA (1969). Effect of chronic nutritional iron deficiency on the small intestine disaccharidase activities of growing dogs. Proceedings of the Society for Experimental Biology and Medicine, 130: 595-598.
9. Sriratanaban A \& Thayer WR (1971). Small intestinal disaccharidase activities in experimental iron and protein deficiency. American J ournal of Clinical Nutrition, 24: 411-415.

10. Lanzkowsky $P$, Karayalcin $G \&$ Miller $F$ (1982). Disaccharidase levels in iron deficient rats at birth and during the nursing and postweaning periods: response to iron treatment. Pediatric Research, 16: 318-323.

11. Lanzkowsky P, Karayalcin G, Miller F \& Lane BP (1981). Disaccharidase values in iron deficient infants. J ournal of Pediatrics, 99: 605-608.

12. Fernandes MIM, Galvão LC, Bertolozzi MF, Oliveira WP, Zucoloto S \& Bianchi MLP (1997). Disaccharidase levels in normal epithelium of the small intestine of rats with iron deficiency anemia. Brazilian J ournal of Medical and Biological Research, 30: 849-854.

13. Fritz J C, Pla GW, Harrison BN, Clark GA \& Smith EA (1978). Vitamins and other nutrients. J ournal of the Association of Official Analytical Chemists, 61: 709-714.

14. Ramsay WNM (1957). Determination of iron in blood plasma or serum. Clinica Chimica Acta, 2: 214-220.

15. Dahlqvist A (1964). Method for assay of intestinal disaccharidases. Analytical Biochemistry, 7: 18-25.

16. Siegel S (1975). Estatística Não-Paramétrica para as Ciências do Comportamento. McGraw-Hill do Brasil, São Paulo, 131144.
17. Graitcer PL, Goldsby J M \& Nichaman MZ (1981). Hemoglobins and hematocrits: are they equally sensitive in detecting anemias? American J ournal of Clinical Nutrition, 34: 61-64.

18. Dallman PR, Refino C \& Yland MJ (1982). Sequence of development of iron deficiency in the rat. American J ournal of Clinical Nutrition, 35: 671-677.

19. J oansson I \& Fargërnas C (1994). Effect of iron-deficiency anaemia on saliva secretion rate and composition in the rat. Archives of Oral Biology, 39: 51-56.

20. Dhur A, Galan P \& Hercberg S (1990). Effect of decreased food consumption during iron deficiency upon growth rate and iron status indicator in the rat. Annals of Nutrition and Metabolism, 34: 280-287.

21. Oski FA (1979). The nonhematologic manifestations of iron deficiency. American J ournal of Diseases of Children, 133: 315-322.

22. Galvão LC, Collares EF, Soares FC \& Brasil MRL (1978). Níveis das dissacaridases no intestino delgado de ratos lactentes submetidos à desnutrição proteico-calórica. Arquivos de Gastroenterologia, 15: 32-39.

23. Dallman $P R$, Sunshine $P \&$ Leonard $Y$ (1967). Intestinal cytochrome response with repair of iron deficiency. Pediatrics, 39: 863-871.

24. Buts J P, Vamecq J \& Hoof FV (1986). Alteration of intracellular synthesis of surface membrane glycoproteins in small intestine of iron-deficient rats. American J ournal of Physiology, 14: 736-746. 